\title{
Determinants of Business Excellence -A Study of Selected Listed Companies in India
}

\author{
Prof Rajendra K Gupta \\ SoBM, Jaipur National University, Jaipur India
}

\begin{abstract}
Need to excel in Business for companies have been emphasized repeatedly in recent global literature. The companies have moved on from quality focus to excellence focus. Several excellence award Models are in use that include European Quality Award given by EFQM, Malcolm Baldrige award in USA and various others. The focus of these models is to win excellence awards and self assessment. Companies should focus on becoming world class organization. There are several business practices that are used by successful and excellent companies. The importance of leadership style, Organization type and strategies, Core values and Growth strategies is fairly established. The companies have been increasingly using Mergers and Acquisitions for rapid inorganic growth to meet global challenges. The paper reports a part of research carried out in sample of best performing Indian listed companies. Less researched determinants used for achieving of business excellence have been explored. The paper presents results of empirical research in Indian companies as also testing of Leadership style typology developed by S. Hart and Organization types proposed by Miles and Snow.

Key Words: Factors of excellence, Business Excellence, Determinants of Excellence, Business performance, Excellence in Indian companies
\end{abstract}

\section{Introduction}

Business Performance Excellence is achieved when an organization is generating the maximum level of profitability possible given the human, financial, capital, and other resources it possesses (Luftig, 2005).Several definitions have been given about business excellence like the definitions given by European Foundation for Quality Management (EFQM) and scholars like Gopal Kanji (2002) and Pravin Rajpal (2007).

However, the author after going through various aspects of excellence believes that: 'Business excellence is achieved by a firm when it is able to procure requisite resources and apply them consistently in a unified manner to deliver superior results over its nearest competitors irrespective of macroeconomic conditions'. Such firms are best-in-class and are companies of endearment to their customers, and for society in general Aim of achieving excellence is to reach a world class status. It is a journey that continues as benchmarks and technologies keep changing with time.

A research project was undertaken from 2009 to 2012 to identify the best practices used globally by top organizations, and to identify benchmarks used by world class companies. Not much work was done in India before at academic level to define excellence and develop excellence model by establishing causality of business practices on business results.

Leadership development, organization communication, and organization strategies form important inputs for success of any organization. Every successful business has some business model and a few key success factors. All successful organizations regularly carry out SWOT (Strength, Weakness, Opportunity, and Threat) analysis and measure the vulnerability of their business to onslaught of globalization, new technologies influx, and rising competition. To make things worse, the changing preferences, rising expectations and diminishing loyalty of customers make things difficult for organizations. We all remember how in early $90 \mathrm{~s}$ consumers suddenly dropped scooters and went in for motorbikes sending great companies like Bajaj Auto in jitters.

Those organizations that excel, often set vision for industry leadership and for future, have developed strong organizational core values that employees identify with, and have succeeded in developing strong brands, which, the customers trust.

The route of mergers, acquisitions, or management takeover of businesses as growth strategies has been fairly established as an important factor for strategic inorganic growth and becoming globally competitive.

The organizations adopt various growth strategies to sustain business and grow in it. Organizations that stagnate loose market share and competitiveness and may ultimately fail. Several strategies adopted by successful organizations were studied and the responses were received from sample companies in India. Hence the data were collected on various aspects of excellence from the best performing listed companies in India to find out how they are organized on various factors and what they think about business excellence. Since most of leading 
companies in India are now operating globally, they are globally competing and their responses may as well apply to companies across the glob

This paper presents relatively less researched aspects of business excellence determinants like leadership styles, Organization type and strategies, Growth strategies adopted by successful firms, critical success factors, and perceptions of companies about what constitutes excellence, in this context.

\section{Review of literature}

Business excellence, as described by the European Foundation for Quality Management (EFQM), refers to "outstanding practices in managing the organization and achieving results, all based on a set of eight fundamental concepts."

These concepts are: "Results orientation, customer focus, leadership, and constancy of purpose, management by processes and facts, people development and involvement, continuous learning, innovation and improvement; partnership development, and public responsibility."

Guile and Fonda (1999) comment, "Businesses have had to learn how to operate more flexibly and how to integrate functionally separated tasks into horizontal work processes. Multi functional teams are replacing management hierarchies as the primary method of delivering results. Organizations have learned to appreciate the significance of their intellectual capital and to be aware of the need to develop and nurture it...." This applies very well to most Services and of course to Design based product sectors like Automobile, Aviation, and Electronics.

In "10 pillars of world class companies" by Success Network International, USA, Two of the 10 pillars mentioned are Communication and Leadership. On communication they assert, "One definition of Business is a network of communication against a background of relationship. Great companies operate with exceptional communication. They tell the truth with compassion. They create more light than heat. All communication-Internal \& external -is honest, clear and on purpose".

On leadership it goes on "No Company can excel and endure without strong, committed leadership. And when leadership is available at all levels, magical things happen. Great Companies are result of excellent leadership that is not dependent upon personalities, but rather on principles, values, and convictions"

Jim Collins (2001) asks the question in his book 'Good to Great', 'Can a good company become a great company and if so, how?' Besides adopting hedgehog concept in which company sticks to what it knows best, making the transition from good to great doesn't require a high-profile CEO, the latest technology, innovative change management, or even a fine-tuned business strategy. At the heart of those rare and truly great companies was a corporate culture that rigorously found and promoted disciplined people to think and act in a disciplined manner.

\section{Leadership style Typology of S. Hart}

Organization Leadership style can be identified as closer to any of 5 choices (rows) below that best describe your organization's leadership style

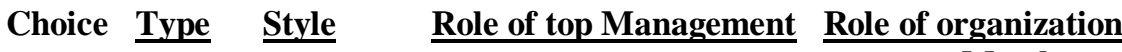$$
\downarrow
$$

A Rational Analytical Boss (evaluate \& Control)

B

$$
\text { Command }
$$

Imperial

Driven by leader

Commander (Provide or a Small team

C Symbolic

$$
\begin{aligned}
& \text { Cultural Coach (motivates \& inspire) } \\
& \text { Driven by mission }
\end{aligned}
$$
\& vision of future

Transactive

Procedural Facil
Driven by internal process and mutual adjustment

E Generative Organic Sponsor (Endorse \& Sponsor) Entrepreneur Driven by organizational actors' initiative
Members

Subordinate (follow

the System)

Soldier (obey orders)

Player (responds to challenge)

Participant (learn \& improve) Enable) (experiment \& take risk) 
It describes how various organization members play role in the process (Hart \& Banbury, 1994).

In above developed typology, Hart identified 5 leadership strategies. For example, in choice 'A' (row) the type of leadership is Rational, the style of leadership is imperial and in such setting the Boss plays role of commander and other members of follower. It is a typical old style of organization that is often used by patriarchal type of owners

Strategy Modes that involve the whole organization are likely to produce more effective strategies than those who do not. Hart also points out that particular mode lead to particular performance output. The rational mode with emphasis on decision control can be associated with financial performance and profitability, while transactive mode which is more consultative and incremental can be related to quality and social responsibility. As organizations become large and complex the strategy-making processes must match that complexity with more people involved in the process. Ansoff (1987) termed this as 'Requisite Variety Hypothesis'.

\section{Organization Strategic style: Miles \& Snow}

(Miles \& Snow, 1978) presented 4 types of organization:
A) Prospector
B) Defender
C) Analyzer
D) Reactor

A prospector organization is better placed to meet future challenges in fluid environment since these continually search for market opportunities. 'Analyzers' are organizations which operate in two types of product-market domains, one relatively stable, the other changing. In their stable areas, these organizations operate routinely and efficiently through use of formalized structures and processes. In their more turbulent areas, top managers watch their competitors closely for new ideas, and then rapidly adopt those which appear to be the most promising The type D is highly undesirable type.

Rockart (1982) defined Critical Success factors or CSFs as those few areas of activity in which favorable results are necessary for a particular manager to reach his or her goals. As for business, Rockart specified that CSFs are the limited number of areas in which results, if they are satisfactory, will ensure successful competitive performance for the organization.

They are the few areas where 'things must go right' for the business to flourish. If results in these areas are not adequate, the organization's efforts for the period will be less than defined. In view of author the CSFs are those which are vital to ensure successful operations and competitive advantage. For example a Mini steel Mill using steel scrap as raw material should have well developed system for importing quality melting scrap at reasonable prices and should have adequate line of credit/funds for this. For a garment retailing chain quickly replenishing designs/apparels moving fast in stores is critical success factor. For retailers leasing out prime locations for stores is a critical success factor.

The definition of excellence in business means remaining ahead of competition and using best practices. It means to sustain growth of the firm strategically to acquire higher capabilities in terms of production facilities, strategic global marketing or procurements, or acquiring newer technology. More often than not it is difficult to achieve organically.

That leaves us to produce new solutions and Mergers and Acquisitions (M\&A) in the context of strategic partnership is the most prominent way of solution to keep pace with the company's competitive conditions and changing market for Globalization (Akgobek, 2012).

Two companies that are recognized as among the best at making successful acquisitions are General Electric and Cisco Systems. These companies have been star performers in growing shareholder value. The core principal that runs through almost every acquisition is integration.

In words of Sun Microsystems Executive Vice President of Corporate Development and Alliances, Brian Sutphin sharing his views on inorganic growth strategies, including mergers, acquisitions, and strategic partnership, acquisitions are one means of bringing to a company the innovation that 'happens elsewhere'. 'But it's important to emphasize that acquisitions complement Sun's organic efforts, they are not a substitute for them. They are also a great way of adding new talent to the company. One criterion that applies to every acquisition, however, is the quality of the people' which factor most often is cause for failures of M\&A

The above review suggests areas for us to focus to study factors that determine excellence in business. The criteria selected were empirically tested in a sample of 75 top performing Indian listed companies.

\section{Research Methodology and Sampling}

The sample companies were selected from 55 important sectors of economy by using sample frame of NSE500 Index listed companies on National Stock exchange. These reflect 95\% of total market capitalization in India. The selection from list was made through 5 point criteria of filtration and then internal comparison of 
financially best performing companies in each sector. Overall a purposive sample of 75 companies was selected that represent best companies in India.

Various factors of excellence and best practices of business that are used in modern successful global organizations were identified through extensive global literature survey

Filtering criteria for sample companies in India:

-Edelweiss score below 5 removed ( fundamentally weak company)

-Turn over/ employee below 20 lacs removed ( low labor productivity)

-EPS below 3 On FV 10 removed ( Low returns on share)

EV/EBIDTA $<3$ and $>25$ removed (extreme cases of EV/EBIDTA ratio)

-RONW below $15 \%$ removed (Low returns on equity capital)

-Sales and profit growth negative values removed ( Loss making company if any)

Edelweiss score (Edelweiss India) represents fundamental strength of companies on their 5 criteria including latest sales and profit growth

Data were sorted by 3 years performance of 2008, 2009, and 2010 ending March. Finally the latest performance up to Q3 of 2011-2012 was also checked before starting analysis.

Foreign owned MNCs were not included in sample since the global MNCs were used as benchmarks to identify various business excellence practices.

This paper presents part of research carried out on factors determining excellence in business. The various responses were collected through questionnaire administered by email/post and follow-up pan-India field visits of surveyors. Survey was conducted between October 2011 and March 2012.

\section{The Determinants of Excellence:}

Leadership, communication, and organization strategy:

The question asked was: Your organization is closer to a-

A) Multi layered, Formal structured, centralized and Complex with written rules and written Communication system

B) Slim, less complex, decentralized and less formalized in terms of supervision \& autonomy

C) Somewhere between A \& B with dual communication- written and verbal.

The summary of responses are given in Table 1

Table: 1 Organization Type
\begin{tabular}{|c|l|l|}
\hline LO & \\
\hline L0 & Frequency & Percent \\
\hline- & 25 & 33.33 \\
\hline A & 31 & 41.33 \\
\hline B & 9 & 12.00 \\
\hline C & 10 & 13.33 \\
\hline
\end{tabular}

Here, we are getting that most of companies are closer to Multi layered, Formal structured, Centralized and Complex with written rules and written communication system. A good $1 / 3^{\text {rd }}$ can't decide how they are organised. Only $13 \%$ companies have slim, agile, and fast response organization structure. Most of them have bureaucratic structure with written communications in place.

\section{Leadership Type and organization values:}

The questions asked:

A-Do you think your organization has a Strong committed and dominating leader at top?

B-Do you think your organization has a strong organization/work culture that employees can identify with?

C-Has your organization been able to develop strong identifiable Core values?

D-Do you think your organization has something that drives customer loyalty and the customers easily identify themselves with your organization

E-Do you think your lower rank employees know about company goals and challenges?

F-Does your organization have multi-task teams?

G-Does your organization have Non-bureaucratic open communication system?

H-Does your organization have Outstanding or Cutting edge Status in one or more business practices (for example Delivery time, Core patented technology, Key industry experts on rolls such as a noted cardiac surgeon in a hospital)?

J-Has the company empowered sales staff for customer related decisions? Y/N/Limited

From below distribution in Fig 1, we see that there is strong awareness about top leadership, delegation, and open communication. However, the sales force empowerment is limited. 
Fig 1: Leadership and Communication responses Bar Chart

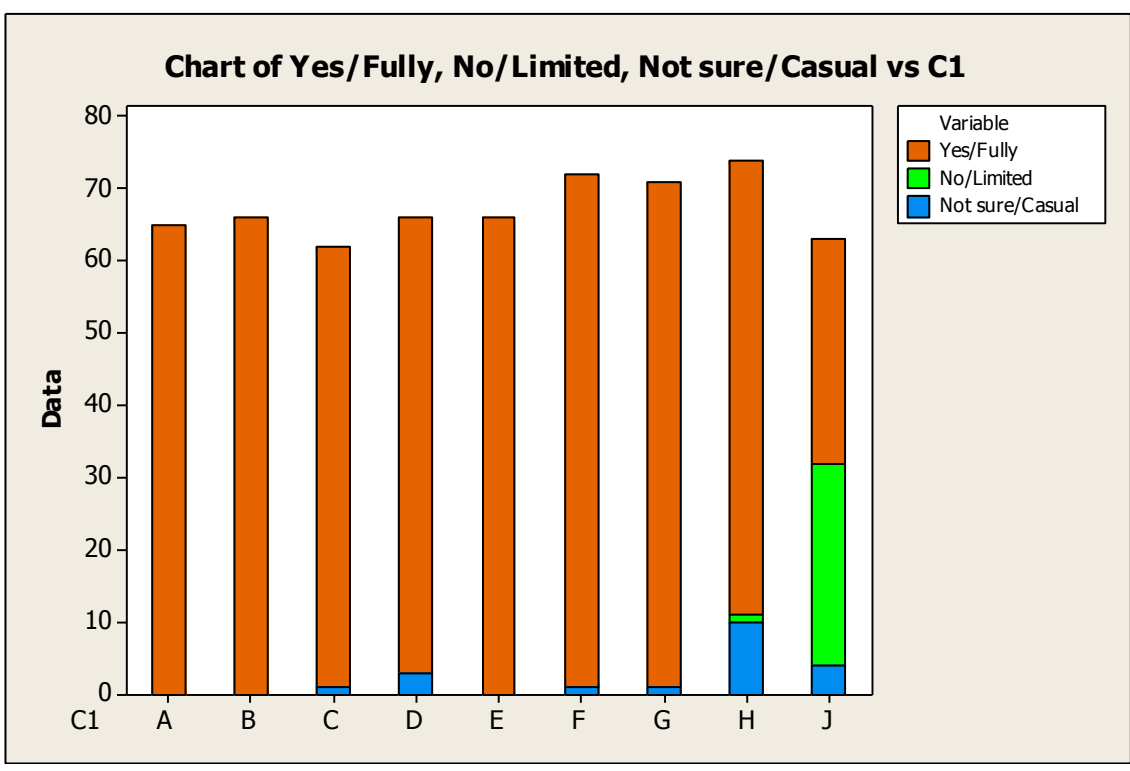

Majority of companies have reported that they have a strong central leadership.

Two factors have emerged as strong organizational features in Indian companies:

1. Use of multi-task teams, and

2. Increasing awareness about Non bureaucratic open communication system.

This is in line with modern practices of Human resource management in leading MNC organizations.

Leadership, Communication, and organization style:

The summary chart of Responses from Companies on Hart's typology is given in Table 2 below:

Table 2 Organization leadership Style Emprical testing of Hart (1992) Organisational leadership Model

\begin{tabular}{|c|c|c|c|c|c|c|c|c|c|}
\hline \multirow{3}{*}{ Choice } & & & & \multirow{3}{*}{ Style } & \multirow{3}{*}{ Resp } & \multirow{3}{*}{$\begin{array}{l}\text { Role top } \\
\text { Managmnt }\end{array}$} & \multirow{3}{*}{ Resp } & \multirow{3}{*}{$\begin{array}{l}\text { Role of } \\
\text { Orgz membs }\end{array}$} & \multirow[b]{2}{*}{ Resp } \\
\hline & Resp & type & \multirow[t]{2}{*}{ Resp } & & & & & & \\
\hline & & & & & & & & & \\
\hline A & 1 & Rational & 35 & Analytical & 15 & Boss & & Subordinate & 9 \\
\hline B & & Command & & Imperial & & Commander & 24 & Soldier & $2+2>$ \\
\hline & & - & & 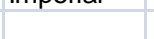 & & 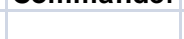 & & 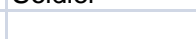 & \\
\hline C & & Symbolic & 15 & Cultural & 16 & Coach & 15 & Player & 24 \\
\hline & & & & & & & & & \\
\hline D & & Transactive & 9 & Procedural & 13 & Facilitatir & 17 & Participant & 18 \\
\hline E & & Generative & & Organic & & Sponsor & & Entreprenur & 9 \\
\hline
\end{tabular}

Only 3 companies picked one choice (entire row like A or E) from 5 choices created in Typology. Majority have picked their own pattern of various parameters. The most dominant pattern that comes out is that the leadership Type is Rational. The style of leadership is Analytical or cultural (driven by Vision and Mission of future).The top management plays role of Commander (Provide direction) or as facilitator (Empower \& enable).Organization members are either acting as players (responding to challenges) or act as Participants (learn \& improve). The situation is far from satisfactory. Either managers in Indian companies are not keen on Leadership and organization development or are confused as to role of leadership in influencing goals and actions for meeting environmental, competitive, and future challenges. Certainly it is not fit for innovation.

\section{Organization's strategic style}

The organization's strategic style is closer to one of following: (The style vis-à-vis interaction with and handling of external Business environment)
A) Prospector
B) Defender
C) Analyzer
D) Reactor

The responses received on organization type proposed by Miles \& Snow are given below in Table 3 . 
Table 3: Organization Strategic Style

\begin{tabular}{|l|l|l|}
\hline L2 & \\
\hline L2 & Frequency & Percent \\
\hline- & 7 & 9.33 \\
\hline A & 28 & 37.33 \\
\hline B & 10 & 13.33 \\
\hline C & 18 & 24.00 \\
\hline D & 12 & 16.00 \\
\hline
\end{tabular}

Looking on frequency distribution above, we can say that most of organizations strategic style is closer to prospector followed by analyzer (Total $62 \%$ ). This is a good sign.

The strategic style of organizations (Miles \& Snow, 1978) consists of 'prospector' $37 \%$ and 'analyzers' 24\%, rest being 'defenders' and 'reactors'.

\section{Growth strategies adopted by organizations:}

Organization strategies adopted for growth, profitability, and competitiveness in recent years (In last 5 years):

In following table 4, frequency distribution is given for organization Growth strategies adopted by sample companies.

Table 4: Strategies for organization growth

\begin{tabular}{|l|l|}
\hline Organization Strategies & Frequency \\
\hline Capacity expansion & 37 \\
\hline Market share increase & 37 \\
\hline Price competitiveness & 35 \\
\hline Leadership Development \& Training & 35 \\
\hline Brand Promotion & 32 \\
\hline Customer Delight and Loyalty management & 28 \\
\hline Managerial empowerment and training & 27 \\
\hline Innovation Promotion \& Management & 27 \\
\hline New customers acquisition & 26 \\
\hline Reducing Time to Market & 23 \\
\hline Innovative financial resourcing & 18 \\
\hline Developing Core competencies & 18 \\
\hline New product launches & 16 \\
\hline Mass Production & 16 \\
\hline Brands acquisition & 16 \\
\hline Automation (operations) & 16 \\
\hline Modular Customized production & 15 \\
\hline Innovative supply chains & 15 \\
\hline Diversification & 14 \\
\hline Product mix enrichment & 14 \\
\hline Value added products & 14 \\
\hline State of Art technology acquisition & 14 \\
\hline R\&D and patents & 13 \\
\hline Financial restructuring; & 13 \\
\hline Made to Stock & 10 \\
\hline Organization restructuring & 10 \\
\hline Overseas marketing & 9 \\
\hline Strategic global alliances & 8 \\
\hline Outsourcing production & 7 \\
\hline Decentralization and autonomy & 5 \\
\hline Automation(marketing) & 3 \\
\hline Debt management & 2 \\
\hline Consumer research & 0 \\
\hline & \\
\hline
\end{tabular}


The top three are most commonly used strategies by organizations globally. R\&D expenditure and patents and strategic global alliances need focus as these are weak points in path to globalization. No company reported consumer research as a strategic tool for growth and profitability. Of course, the companies are using multiple strategies from the above list.

\section{Vision for Industry leadership and Brand ranking:}

The respondents were asked if they have set vision for attaining global and domestic leadership in their industry and where do they think their flagship brands stand in domestic and global markets, respectively. The summary of responses is given below.

\begin{tabular}{|c|c|c|}
\hline Already Achieved Globally & 0 & \\
\hline Already Achieved India & 6 & \\
\hline Vision for Top 5 Globally: & 19 & \\
\hline Vision for Top 5 India & 29 & \\
\hline Domestic Brand Status: & 33 & \\
\hline Global Brand status & 3 & \\
\hline
\end{tabular}

A look at above statistics and pattern in table indicate that Indian companies are far from being world class and very small numbers of these have set any vision for global leadership. Unless the company has strong leadership at top driven by Vision and Organization culture, it is difficult to achieve and sustain excellence.

\section{Vulnerability Perception of Companies}

The summary of scores given by companies regarding their vulnerability to environmental threats on a scale of 0 (NIL) -100 (Worst) are statistically compiled and presented below in Fig 2.

Variable $\mathrm{N}^{*}$ Mean SE Mean St Dev Minimum Q1 Median Q3

$$
\begin{array}{llllllll}
52 & 0 & 42.50 & 2.43 & 17.50 & 20.00 & 30.00 & 40.00 \quad 50.00 \\
90.00
\end{array}
$$

Fig 2: SWOT Perception of Companies Frequency Diagram

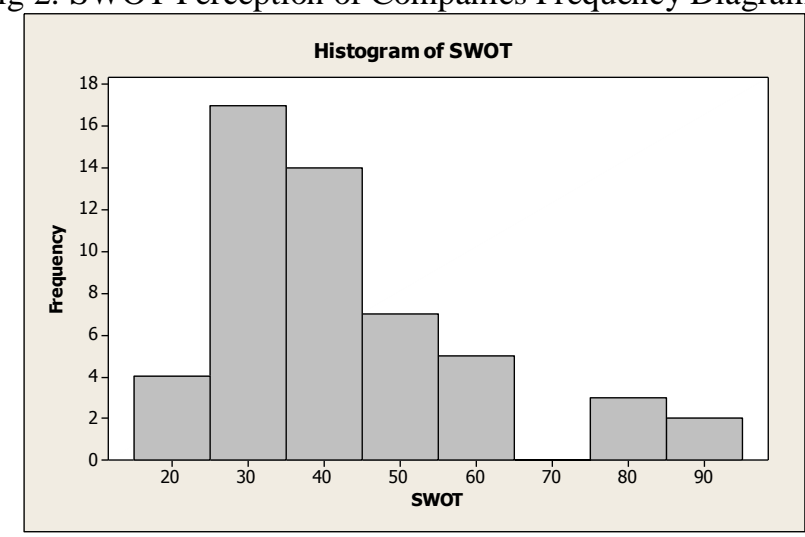

It is good to note that Indian companies have lower threat perception i.e. below 50 on a scale of 0-100. It may also be due to relatively high protection provided in Indian policy regulations and Indian markets. As seen in Growth strategies section, Indian companies have taken several steps including expansion of facilities for economies of scale, competitive pricing, value added products and overseas operations directly or through M\&A route.

\section{Key Success Factors:}

The question was asked to various sample companies as to what they think were key success factors for their business. A wide range of factors were mentioned by various companies. These were different for most of the companies. Hence one can conclude that each company determines its own business model and lays down key success factors which determine its profitable operations, growth and sustainability goals.

It is not possible to standardize a few key success factors that can be followed across companies as a uniform and common practice.

The summary of responses received is given in table 5 below:

Table 5: Key success factors and number of responses

\begin{tabular}{|l|l|}
\hline Product design and pricing & 1 \\
\hline Integrated service from design to after sales service & 1 \\
\hline Aggressive Advertising & 1 \\
\hline Collaborations & 1 \\
\hline
\end{tabular}




\begin{tabular}{|l|l|}
\hline Economies of scale & 1 \\
\hline Visionary leadership at top & 1 \\
\hline Vision and mission well communicated & 1 \\
\hline New products & 2 \\
\hline Product range/portfolio & 2 \\
\hline Strong \& old Brands & 2 \\
\hline Technology and ITES & 2 \\
\hline Globalization of operations & 2 \\
\hline Distribution network and segmentation & 3 \\
\hline Time to market reduction & 3 \\
\hline Pioneering company & 3 \\
\hline R\&D \& product Innovation & 4 \\
\hline Employee training and empowerment & 4 \\
\hline High quality products & 4 \\
\hline Competitive pricing & 4 \\
\hline Quality Service & 5 \\
\hline Product differentiation/ diversification & 8 \\
\hline Customer focus \& customer loyalty & 9 \\
\hline
\end{tabular}

Obviously emphasis of companies is on marketing related factors.

\section{Winning strategies carried out in last 10 Years:}

The companies were asked to identify any winning strategies they devised in last 10 year period that gave them significant competitive advantage or changed rules of the game in their Industry.

The responses by sample companies are summarized below:

$\underline{\text { Services sector companies }}$

HCL Info systems Ltd

Shopper Stop Ltd

Spicejet

Mahindra Holidays

Cox \& Kings

Everonn Education

TCS

ICICI Bank Ltd

Tata Power

Oberoi realty Ltd

Kovai Medical Centre

Bharti Airtel

Eclerx Services

Manufacturing Sector Companies:

TTK health Care

Tube Investment

L\&T

Coromandal International

Jayshree Tea

Sintex Industries

Indian Oil

Pidilite Industries

Tata chemicals
Outstanding Human resource practices

Factory assembled and modular plants

Repeat customers due to high satisfaction

Introduced low cost fares

Quality Service \& Hospitality

Product/resorts

Competitive pricing

Good after sales service

Technology Innovation in Education \& Training

Outstanding Human resource practices

Personal Finance Management

Aiming always for highest possible standards

Contemporary Architecture

Strong Project Implementation

High Quality Construction

Latest developments in Medical Science

Building strong Brands

Strong services Portfolio

JV with Sara lee/SSL/Eva

Innovation

Durability of products

Quick decision making

Rapport with OEMs

Market Share Analysis

Fast response to market situations (Commodity)

Made significant capital investment after thorough

Demand analysis

Revamped Distribution Network \& Filling stations

Value added products marketing strategy

Value chain concept 


$\begin{array}{ll} & \text { Corporate Governance } \\ \text { Tin Plate Company (Tata) } & \text { Adopting Green purchase policy } \\ \text { Cadilla Healthcare } & \text { Focus on anti-hypertension drugs } \\ & \text { Patents \& new product launches } \\ \text { Dabur India } & \text { Building Strong Brands }\end{array}$

This question was asked to companies to bring out if these top performing organizations had any winning strategies that put them in leading position in their industry and changed the rules of games. However, results are not encouraging. In fact none of the companies has reported such gains. The careful analyses of contents above show that organizations do adopt strategies, but these can't be called game changing strategies making them qualify for innovative organizations. Perhaps the strategies mentioned by Indian Oil and that of Spice jet come somewhat closer to such winning strategies.

Winning strategies are those measures that are innovative and give significant competitive advantage to the adopter which is difficult to follow quickly and which alters the business model of that industry. Deccan Airlines brought innovative pricing strategies of low cost flying and free seats, but could they succeed in long term? Winning strategies are often adopted by world class companies which hit the nail direct on head of nearest or major competitors. A winning strategy should generate fresh demand from consumers or outdo competitors catching them on back foot.

\section{What the companies think about excellence in Business?}

According to respondent companies the practices that determine excellence in business are. Item given in brackets is related focus area.

Manufacturing sector:

BHEL (Power Equipment) - Support continuous change effectively (Kaizen) Motivation of employees (HRM)

Shree Renuka (Sugar): Customer satisfaction is measured regularly for improvements (Customer satisfaction)

Eicher Motors (Tractors): Implement new ideas frequently (Innovation orientation)

Hindustan Zinc (Non Ferrous): Integrated Aluminum Strategy \& Multiple Brownfield Expansion (Expansion)

Maharastra Seamless (Pipes and steel sheets): Leadership development \& Training; Talent Spotting (HRM)

Dabur India (Herbal products, FMCG): High Quality (product Quality)

Ranbaxy Lab (Pharma): Sustained Operational \& Strategic synergies (strategy)

Cadilla Healthcare (Pharma): Top quality products (product quality)

Carborundum Univ (Abrasives): (customer satisfaction)

Voltas Ltd (Air conditioning): Product \& service quality (product quality)

Uflex Ltd (Plastic packaging): Product quality (product quality)

Systematic Channel distribution (SCM)

Reduce order lead time (World class parameter)

Sesa Goa (Mining ores): Flexible and flat organization (Decision Making \&Response time)

Spice Mobility (Telecom equipment): Top product quality (Product Quality)

Tin Plate Co. (Steel Mills): Ethics \& values

Tata Chemicals (Essential life chemicals): High ethics \&Moral standards (ethics \& value); High standards of performance (World class parameters)

Hindalco (Non Ferrous metals): Setting reasonable targets (achievable goals)

Pidilite Industries (Adhesives): Creative marketing

Tata Steel (Steel plants): TQM Model

Indian Oil (Refineries): Commitment to Vision

Havels India (Electric goods): Trust \& Self devotion to excellence (HRM)

Jain irrigation (Pipes, sprinklers): High product quality (product quality)

Mahindra \& Mahindra (Automobiles, diversified): Low cost High quality Strategy (Competitiveness)

Bajaj Auto (Automobiles): High exports share (Global competitiveness); Market segmentation \& Product portfolio like Premium, executive and Economy mobikes.

Elgi Equipment (compressors equipment): Leadership (HRM)

Product Quality

Fedders Lloyd (Air conditioning; engineering): Stretching goals with support of management (employee productivity)

Crompton Greaves (Electric goods, Transformers): Internal communication \& Employee engagement (HRM)

MRF (Tyres \& Sports goods): Clear communication.

Tata Motors (Automobiles): Self devotion \& trust to excellence (HRM) 
International product designs (global markets)

Jayshree tea (Tea): Preferred supplier to key customers (Customer Loyalty)

Bharat Electronics (Electronics equipment): Corporate goals communication (HRM)

Coromondal International (Fertilisers): Competitiveness benchmarking (Strategy)

Dr Reddy's Lab (Pharma): Technology \& leadership (HRM)

SRF Ltd (Textiles \& Fibres): Quality audit of suppliers (ISO 9001)

Oil India (Petroleum): Trust; Quality (Product Quality)

NRB Bearings (Engineering bearings): Product \& Service quality; Customer satisfaction

UltraTech Cement (Cement): Product Quality; A low lead time (World class parameter)

Symphony Ltd (Coolers): Employee productivity (Productivity)

Rane madras (Auto components OEM supplier): Point of need movement of employee (world class parameter)

Asian paints (Paints \& Chemicals): Aim to be Global leader at $5^{\text {th }}$ position (World class parameter)

L\&T (Engineering/ Diversified): Self devotion \& Trust (HRM)

Hindustan Liver (FMCG): Strong Brand Portfolio straddling entire consumer Pyramid;

Market segmentation and Branding (Marketing)

Siyaram Silk Mills (Textiles): Employee productivity (Productivity)

Tube Investments (Precision tubes/Cycles): Communication; TQM; Innovation \& Research (TQM)

TTK Healthcare (Pharma/Food products): Product quality

Services sector:

Bajaj Finserve (Financing): Right direction \& Vision of company (Strategy)

Eclerx Services (ITES): Risk Management \& Customer value

Glodyne Technoserve (Software): Top service quality.

Infosys (Software): Deep commitment to TQM

Bharti Airtel (Telecommunication): Customer satisfaction measurement

Kovai Medical Centre (Research Hospital): High Skill Company in Oncology

ICICI Bank (Banking): One stop bank for financial solutions (Mission)

Tata Power (Power utility): Power distribution management

Integrity \& responsibility (Business Ethics)

Oberoi Realty (Real estate): Timely delivery (World class parameter)

Product quality

Hindustan Media (Multi-Media): Internal Communication; Work environment

Sun TV Network (Media): Internal communication; Stretching goals with support

TCS (Software): Top service quality (Customer Satisfaction)

PNB (Banking): Open communication \& interactive management style

IL\& FS Transport Network (Infrastructure): Trust, Self devotion \& Participation (HRM)

Everonn (Education): Vision of becoming global player; Innovation

Cox \& Kings (Travel): Flexible fast response organization

Deccan Chronicle (Print Media): Talent retention; T\&D (HRM)

Mahindra Holidays \& Resorts (Timeshare/Hotels): Effective \& aggressive marketing (Marketing)

Spice jet (Aviation): Low cost operator (Competitiveness)

Axis Bank (Banking): Service Quality

Shoppers stop (Retail): Variety of products

Importance to customers

HCL Info systems (Computers): Top service quality

Only three companies in sample believe that adopting an independent Excellence model results in excellence like, using EFQM/ CII-EXIM award model.

\section{Mergers \& Acquisitions}

The question was asked to companies about M\&A carried out by them in recent years. The responses are summarized in below table 6 and Table 7

Table 6: Merger/Acquisitions

\begin{tabular}{|l|l|l|}
\hline Mergers carried out & Frequency & Percent \\
\hline Missing & 28 & 37.33 \\
\hline No & 27 & 36 \\
\hline Yes & 20 & 26.67 \\
\hline
\end{tabular}


Table 7 Number of M\&A entered by companies

\begin{tabular}{|l|l|l|}
\hline Mergers count & Frequency & Percent \\
\hline Missing & 27 & 36 \\
\hline 0 & 26 & 34.67 \\
\hline 1 & 6 & 8 \\
\hline 2 & 3 & 4 \\
\hline 3 & 7 & 9.33 \\
\hline 4 & 5 & 6.67 \\
\hline 5 & 1 & 1.33 \\
\hline
\end{tabular}

We can see that M\&A is not so popular in Indian sample companies. The maximum number of Mergers/Acquisitions done by any company is 5. Only 30\% companies have reported any M\&A. 36\% respondents did not answer these questions.

\section{Conclusions}

This paper has presented a part of research conducted in sample of top performing listed companies in India. A sample of 75 companies was drawn to study various aspects of business excellence. Relatively less researched areas are focused here. These include Leadership qualities, importance of leadership at multiple levels, Leadership style, Communication, importance of vision for industry leadership, brand ranking, and the critical success factors.

Successful and best-in-class companies employ winning strategies that gives them significant competitive advantage in creating value for customers and improving business performance. Many times these strategies turn out to be game changing for the entire industry in which firm operates. The importance of above determinants of business excellence was tested in our sample companies.

It comes out that Indian companies have taken several steps post liberalization since 1991. The firms have adopted multi-tasking teams. The need for strong core values, strong leadership, and customer loyalty are well recognized by firms. However, the sales force empowerment is low. Majority of organizations have a formal bureaucratic control structure. The typology developed by Hart for leadership style could not be validated in Indian companies. There is mixed type of roles found for boss and subordinates in organizations. It is important that various levels in organization are involved and leadership is developed across the organization to make a flexible, innovative, and world class organization. The organization type is either prospector or analyzers. A prospector type of organizations is best suited for achieving excellence and innovator status.

Very few organizations (25\%) have set vision for attaining global leadership, within top 5. Unless high vision is set and has clear direction, people will not commit to better and different ways of working.

Winning strategies are those strategies that change the rules of game in the specific industry giving at least midterm advantage to the firm. However, it is seen that not many significant strategies are reported by firms. It is not so easy and not frequent, anyway. But to achieve excellence firms should focus on creating value for customers and devise some winning strategy.

The perception of excellence practices in Indian companies is quite diverse and companies have reported focus on human resource development, customer satisfaction, product quality, TQM and cost competitiveness. Wide variety of processes used for achieving excellence collaborate the complexities of the concept of excellence and several approaches that are available to firms. The results are slow and tedious for such measures.

The Indian firms have reported low level of mergers/acquisitions carried out for strategic inorganic growth to meet global challenges. Companies have to move on from achieving the best to thinking of what next, to become innovative. As regards environmental threat, on average, the sample companies which are top performers have lower threat perception.

\section{References}

[1]. Ansoff, H.I., \& McDonnell, E. (1990), Implanting Strategic Management (2nd Edi.), Prentice-Hall, New York. p 118-125

[2]. Akgobek, Ibrahim (2012). Mergers \& Acquisitions as Growth Strategies. IEDRC, International Conference on Business, Economics, and Behavioral Sciences (ICBEBS'2012) April 13-15, 2012 Pattaya, Thailand

[3]. Armstrong Michael and Baron, Angela (2002) Strategic HRM: Key to improved business performance. CIPD Publishing, USA

[9]. Collins, Jim. (2001) Good to Great: Why Some Companies Make the Leap, and Others Don't (Hardcover). Pearson. USA

[10]. Collins, Jim and Porras, Jerry I. (2002) Built to Last: Successful Habits of Visionary Companies. Harper Business USA

[11]. Guile, D., and Fonda, N. (1999) Managing learning for added value. London, Institute of Personnel and Development, USA

[12]. Hart S (1992). An integrative framework for strategy-making process. Academic Management Rev., 17, 1992, s. 327.351.

[13]. Hart S. and Banbury C (1994). How strategy-making process can make a difference.

[14]. Strategic Management J., 15, 1994, s. 251.269

[15]. Kanji, Gopal K. (2002) Measuring Business Excellence. Routledge. London 
[16]. Luftig, Jeffrey Dr. (2005). What is business performance excellence? Centre for Statistical Solution. http://csscu.com/index.php/bpe/bpe-articles-t/40-what-is-business-performance-excellence/downloaded 1-3-2013

[17]. Miles, Raymond E. and Snow, Charles C. (1978). Organizational strategy, structure, and process. McGraw-Hill Book Co. NY

[18]. Rajpal, Pravin. (2007) Achieving Business excellence. Om Books International, India.

[19]. Rockart, J. F. (1982) The changing role of the information systems executive: a critical success factors perspective. Sloan Management Review, Fall, 24(1): 3-13

[20]. Success Network International. (2013) 10 Pillars of a world class company. http://successnet.org/files/10PillarsWCB.pdf/ Downloaded 12-03-2013 